\title{
History Learning Based on Value of Syech Abdurauf As-Singkili Manuscript to Improve Gender Equality Awareness
}

\author{
Mawardy As Ary Putra \\ History Education Department, Post Graduate School of Education, Sebelas Maret University \\ mawardyasaryputra@gmail.com
}

\begin{tabular}{ccc}
\hline Received & Accepted & Published \\
$24 / 03 / 2018$ & $28 / 04 / 2018$ & $30 / 04 / 2018$ \\
\hline
\end{tabular}

\begin{abstract}
Local culture-based education has an important role in character building for students. In a scientific heritage, there are values of wisdom that can be applied in everyday life. The values of this wisdom are reflected in the work of an Acehnese scholar Search Abdurrauf as Singkili, later written in several Manuscripts: Mir'atul Thulab Fe Bag-lubang Ma'ritah Ahkamisy Syar'iyah Lil Mulkil Wahhab and Turjumanul Mustafid. Hence, the history-based learning model of Syech Abdurrauf as a Singkili script was developed. This development is expected to improve students' sense of understanding and awareness about gender equality. From the values listed in Syech Abdurrauf Singkili's text, students are expected to be able to know the value of local wisdom, to develop a pattern of understanding of gender equality awareness both within the scope of school and community, and to raise awareness of equality in Islam. Result: $\mathrm{n}=28$ and $(\alpha)=0,05$, post-test value 0,913 , T-test $2,279, \mathrm{n}=200>0,05$, post-test 0,430 . There is a significant increase in the study of the development of this model, it is expected that with this model of learning history able, develop a gender equality awareness of the students.
\end{abstract}

Keywords: learning history model; Syech Abduurauf As Singkili; gender equality awareness.

Abstrak Pendidikan berbasis budaya lokal memiliki peran penting dalam pembentukan karakter bagi siswa. Dalam warisan ilmiah, ada nilai-nilai kebijaksanaan yang dapat diterapkan dalam kehidupan sehari-hari. Nilai-nilai kebijaksanaan ini tercermin dalam karya cendekiawan Aceh, Search Abdurrauf sebagai Singkili, yang kemudian ditulis dalam beberapa Manuskrip: Mir'atul Thulab Fe Bag-lubang Ma'ritah Ahkamisy Syar'iyah Lil Mulkil Wahhab dan Turjumanul Mustafid. Oleh karena itu, model pembelajaran berbasis sejarah Syech Abdurrauf sebagai skrip Singkili dikembangkan. Perkembangan ini diharapkan dapat meningkatkan pemahaman dan kesadaran siswa tentang kesetaraan gender. Dari nilai-nilai yang tercantum dalam teks Syech Abdurrauf Singkili, siswa diharapkan dapat mengetahui nilai kearifan lokal, untuk mengembangkan pola pemahaman kesadaran kesetaraan gender baik dalam lingkup sekolah dan masyarakat, dan untuk meningkatkan kesadaran kesetaraan di Islam. Hasil: $n=28$ dan $(\alpha)=0,05$, nilai posttest 0,913, uji T 2,279, $n=200>0,05$, post test 0,430. Ada peningkatan yang signifikan dalam studi pengembangan model ini, diharapkan dengan model pembelajaran sejarah ini mampu, mengembangkan kesadaran kesetaraan gender siswa.

Kata Kunci : model pembelajaran sejarah; Syech Abduurauf As Singkil;, kesadaran kesetaraan gender. 


\section{INTRODUCTION}

The field of education is a very broad object. Its scope covers all human experience and thought about education. If we study the papers that discuss education, both the science of education (philosophy of education) and the philosophy of education, then we will find various kinds of understanding or a diverse description of education. The deliberations generally range from basic and educational goals, educational processes, educational materials, and ideal policies as well as operational policies of education.

Dynamics of understanding of education proceed through three moments of the moment of history, reflective moments, and practical moments. The moment of history is a business that reflects the experience of mankind grappling in living up to the concept and practice of its special education, in the wake of developing character education for the students in accordance with the context of the era. A reflective moment is a moment through which human intellectual understanding tries to define its experience, trying to see the methodological, philosophical, and principal issues that apply to character education. The practical moment, that is, with the conceptual theoretical understanding, a human being trying to find effectively so that educational character project can be effective on the field (koesoma, 2007: 308). Education and teaching are the duties and obligations of the human beings who care about the quality of the children of the nation. To realize these goals, various steps are carried out by the world of education, especially related to human resources that directly handle education and learning activities, namely teachers.

Teachers are adults who are consciously responsible for educating, teaching, and guiding learners. The person who is called the teacher is the person who has the ability to design a learning program and able to organize and manage the class so that learners can learn and ultimately can reach the level of maturity as the ultimate goal of the educational process. Another opinion states that teachers are essentially educational personnel who bear the heavy responsibility of humanity, especially related to the process of education of the next generation to the gate of enlightenment in escape from the shackles of ignorance. (Trianto, 2009: i).

Local culture-based education has an important role in character building for students, this is because local culture-based education can explore and develop the value of wisdom in the scope of society. One of them by knowing an influential figure in an area. This historical learning based on local wisdom is expected to generate local potential which has been marginalized and eliminated from public attention. As for some types of local wisdom, education is like manuscripts, traditional games, dances, music and others. Education based on local culture can be taken good education.

The value of local wisdom as well, we can develop a historical education from a figure who contributes to an area and the study of local culture. Of the many figures that we can 
identify from one's life to be utilized into learning materials in the formation of character. One of the benefits is to explain the life of a person who is a role model in his community. The life of this character can be examined by tracing his life experience. The life experience of this character is learned by studying his life in a part.

The existence of a character can be seen from how the influence of the character or contribution of the figure in life, both personal life and community life. This means that there is something very useful from someone who becomes a role model in society, such as the influence of figures in the development of Islam, or the development of education. In this case, the role or contribution made to make the person a very important person in life and society.

In the formation of both cultural and educational character must be mutually related and mutually supportive. Culture has cultural values that function and able to shape the supporting human character. The educators must be able to explore cultural values needed to build the character needed by the nation. But the most important thing is education should be able to form a personality that is good to have good character and useful for the nation. Character based on good morals. Moral derived from the value of cultural values, and especially received support from religious teachings and beliefs embraced human Indonesian human (Simanjuntak, 2014: 20)

Based on observations and field observations, currently there is a tendency that the subject of history is less desirable learners, this is because the history teacher is still much focused on the conventional learning model, less supported by the use of innovative models and media learning, lesson history learning process aspects of social values and social skills, as well as during this historical learning tend to use the ability to memorize learning materials. Lack of teacher ability to integrate subject matter through local wisdom that exists in student environment so that less teacher can improve student learning result and skill. From these observations, the authors see the problems that occur in schools that is, still a lack of understanding in the school environment, issues of equality in education, such as gender equality problems or similarities in learning without having to pick and choose the sex in learning.

Through the development of historical learning model students are expected to be able to gain experience empirically and be able to apply the values obtained in the subject into real life and can, preserve the local culture that students have so as to improve student learning outcomes and social skills. On the basis of the above description, the authors are interested in preparing a study entitled "Development of Learning-Based History Model Values Syech Abdurrauf As Singkili Manuscripts To Increase The Gender Equality Student Equality".

Based on observations and field observations, there is currently a tendency that history subjects are less interested in learners, this is because the history teacher is still much focused 
on conventional learning model, less supported by the use of innovative models and media learning, lesson history learning process aspects of social values and social skills, as well as during this historical learning tend to use the ability to memorize learning mater. The lack of ability of teachers to integrate the subject matter through local wisdom that exists in the student environment so that the fewer teachers can improve student learning outcomes and skills. And from these observations also the authors see the problems that occur in schools that is, still lack of understanding in the school environment will be the problem of equality in education, such as gender equality problems or similarities in learning without having to pick and choose the sex in learning.

Through the development of historical learning model students are expected to be able to gain experience in empirical and can apply the value of values obtained in the subjects into real life and can, preserve the local culture that students have so as to improve learning outcomes and social skills of students. The manuscript is one form of the cultural treasury, containing written text on various thoughts, knowledge, customs, and behaviour of the past. Compared to other forms of non-Indonesian material cultural heritage in Indonesia, such as temples, palaces, mosques, etc., the number of cultural relics in the form of manuscripts is far greater (Ikram 1997: 24).

The realization that manuscripts or ancient manuscripts are the most authentic source of knowledge about the identity of mankind and the cultural background of its predecessor can be realized in an attempt to preserve, review and preserve it (Jabali, 2010: 30). The real manuscript is a tradition that lives in a society that reflects the progress of civilization (civilization) children of the nation who have it. The manuscripts contain the deity, the teaching of manners, the history, the people's stories (fairy tales, legends), traditional technology, mantras, genealogy, amulet, poetry, politics, government, law, customary law, traditional medicine, saga, etc.

The text is a handwritten essay that holds various expressions of thoughts and feelings as a result of the culture of the nation of the past (Baried et al., 1994: 55). The word manuscript is taken from Arabic, ie the word al-naskhah which has an Indonesian equivalent of the word manuscript (Fathurahman, 2010: 4-5). The word manuscript is also a translation of the Latin word, the 'codex' (the singular form, the plural form of codies) which in Indonesian is translated into a script 'not a codex'. The word codex 'in Latin denotes the connection of wood utilization as a base which basically means the word' tree trunk '. The word 'codex' then in various languages is used to denote a classic work in the form of a script.

As far as the searches that have been done by some countries are certainly kept the manuscript collection of the archipelago, such as the Netherlands, England, Malaysia, France, Germany, Russia, Africa, South, Sri Lanka and in some other countries. In addition, there 
appears to be an institution allegedly has a collection of manuscripts Archipelago, because it had a historical history of science such as Dar al-Pole library and al Azhar library in Cairo.

Among the various categories of manuscripts of the archipelago, the text of religious (Islam) is one of the relatively many manuscript categories. This is not surprising, considering the fact that when Islam with all its cultural richness entered the archipelago in general and the Malay-Indonesian territory in particular, the writing culture has been relatively well established, so that when there is contact between Islam and the writing culture, writing activities of religious scripts that are the most effective medium in the process of transmitting Islamic scholarship.

In addition, the number of religious texts, especially the element of Sufism is also related to the fact that culture has Indonesian nation until today as a whole is the result of the acculturation process of Indonesian man with Islamic civilization. As a whole is the result of the process of human acculturation of Indonesia by Islamic civilization which according to Edi Sedyawati is mentioned as one of three great experiences in acculturation in Indonesia. (Edi Sedyawati "Responding to Cultural Heritage" in Media Indonesia, 25 March 2000). Moreover, it is known that since the 13th century, the nation of Indonesia has been visited by the Sufi scholars who in the process of spreading Islam also produced many writings, which are now stored in script form, concerning the teachings of Sufism that they convey to the local community.

In the context of this religious text, the scientific transmission process as mentioned above, in turn, forms two sets of scripting languages: first, manuscripts written in Arabic; and secondly, manuscripts written in regional languages. In scientific manuscripts, religious scripts contain a very diverse field, such as fiqh, tasawuf, Tafseer, hadith, and others. Among the regional languages in the two Malay Indonesians became the means of transmitting various teachings of Islam through their manuscripts, Malay is one of the most widely used languages. This is possible because in the 14th - 15th century when the Islamization process took place, Malay became the lingua franca language in this region. In addition to the Malay language, Javanese language, also no less important language that later enriches the wealth of Islamic scholarship when this language is used to write the teachings of Islam are all delivered orally (Ikram: 1997: 139).

As time goes by, and with the wider scope of territory and with the wider coverage of Islamization territory, the distribution of the text of the word of religion is wider. In turn, when the manuscript is read, understood, and impregnated the content by people in various regions, it also appears various forms of appreciation and reception of the reader community, which then in pour in the form of script writing which later in pour also in the script writing, which in this case is referred to as a "local manuscript" to shorten between manuscripts made in Arabic 
which include written with non-Malay Indonesian scholars with manuscripts written in local languages. The manuscript is the treasures of the archipelago. Local manuscripts were written in various regional languages such as Aceh, Malay, Java, Sundanese, Sasak, and Wolio. (Fathurrahman 2008: 18).

The book that became a reference in this study is the book Mir'atul Thulab fi Bag-hili Ma'ritah Ahkamisy Syar'iyah lil Mulkil Wahhab and Turjumanul Mustafid. These two books of the masterpiece of Syech Abdurrauf are the books that until now have been the study of Silam in the world. The Book of Mir-atul Thullab consists of 3 chapters/discussion:

a) Fiqh Law, both muamalah issues, marriage and all family issues, including inheritance problems (faraidh: division of inheritance), including the laws of the country's land heritage, and all the produce of the earth in it.

b) Ba'i Law (buying and selling issues and all matters contained therein, the law of profit and interest).

c) Jinayah Law (enforcement of sharia law, including civil and criminal law or contemporary issues).

Islam is a religion that governs almost all human life issues. The interpretations made by Abdurrauf in Tafsir Tarjuman al-Mustafid and Mir'atul Thulab fi Tas-hili Ma'ritah Ahkamisy Syar'iyah lil Mulkil Wahhab on some verses of Gender are considered extensions of the classical (patriarchal) interpretation, this can be seen in interpreting verses with the understanding that men have authoritarian rights to women are in contrast to his role in politics he criticizes the growing tradition in terms of leadership that more feature role of men and as evidence is a form of support provided by Abdurrauf against Sultanah Tajul Alam Safiatuddin Shah who was then rejected by the ulama leaders in Aceh and at that time also emerged support of the great scholars to support him namely Shah Nur al-Din Ar-Raniry and Sheikh Abdurrauf as-Singkil so Sultanah increasingly strong in politics. Here there is a difference of thought in the theological stages with factual reality seen Abdurrauf as-Singkili controversy in expressing his opinion and the impact that arises from this as if the Koran as a grand those not able to answer the problem of reality that occurred. This is what makes the researcher interested to examine the interpretation of the gender verse in Tarjuman al-Mustafid and relate that thought to the reality that existed in the time of Abdurrauf as-Singkili lived and applied his various gender ideas. Moreover, the figure of Abdurrauf as-Singkili as Qadhi Malikul Adil certainly his words and thoughts can be a consensus in shaping the discourse of the development of thinking on women's leadership.

Abdurrauf as-Singkili, as the commentator who became the focus of this study, interpreted the word "awliya" by "compiling (cooperating)". The perfect interpretation of Abdurrauf as-Singkili is this: Beginning all the mu'min of men and all the women's mu'min half 
of them are gathering half of them to enjoin them for good works and to keep them from evil work. Who will again be pitied by Allah ta'ala that the greatest power is not exorcised, rather than resolving his promise no more judge but in place. If the interpretation of Abdurrauf asSingkili is compared with the previous interpretation of the question of leadership, Abdurrauf as-Singkili's interpretation position is an extension the hands of Middle Eastern interpretations with the exception of Baidhawi and Jalalain's commentaries. Abdurrauf as-Singkili's view seemed more moderate and tolerant, he did not abandon the interpretation of the word "awliya" as a keyword in equalizing men's and women's rights. In contrast to the two commentaries (Baidhawi and Jalalain) who seem to have little regard for the word "awliya" in their interpretation. So the focus of the second interpretation on the question examines the differences with the conditions of the hypocrites in the previous verse.

\section{METHOD}

The subject of the research is the students of grade X SMA N 1 Gunung Meriah Kec. Mount Meriah, as well as teachers of historical subjects. In this case, the researchers collaborated with teachers and students to develop the learning model based on Syech Abdurrauf As Singkili Manuscript which has been adapted to the standard of competence regarding the entry of Islam in the archipelago and the basic competence is about the kingdom of Islamic kingdom in the archipelago.

Borg and Gall (2003: 569) define development research as follows: Educational Research and development $(\mathrm{R} \& \mathrm{D})$ is a process used to develop and validate educational products. The steps of this process are usually referred to as the R \& D cycle, which consists of studying the research findings, the field testing it in the setting where it will be used eventually, and revising it to correct the deficiencies found in the filed-testing stage. In more rigorous programs of $\mathrm{R} \& \mathrm{D}$, this cycle is repeated until the field-test data indicate that the product meets its behaviorally defined objectives.

Data analysis technique is done to draw conclusions about the data required. In this study, the authors use qualitative data analysis techniques with an inductive approach. The point is that researchers started this research started from the fact that the ability of learners still not fully understand about the manuscript of Syech Abdurrauf as Singkili. Thus the theory is required that the learning of history requires a means to achieve results can be maximized, not only academic ability but also social cooperation both within and outside the school. From the data obtained will be grouped into three namely (1) interview data, (2), school archives, and (3) class data.

1. Introductory Research Instrument

In the process of collecting data, researchers need some supporting instruments, such as questionnaires, interview sheets, and observation sheets. To support the instrument is needed some tools such as cameras/video, voice recorder, and field notes.

2. Data Triangulation. 
According to Sugiyono (2012: 330) triangulation defined as data collection techniques that are combining from various data collection techniques and data sources that already exist. There are two kinds of triangulation. The first is triangulation technique which means the researcher uses different data collection techniques to get the data from the same source. Second, meaningful source triangulation to obtain data from different sources is different from the same technique.

\section{RESULT AND DISCUSSION}

Equivalence Test Result, Improvement Test and Effectiveness of Manuscript Based Learning Model Syech Abdurrauf As Singkili.

Equality test, Improvement test and Effectiveness test of this learning model are done by conducting competence test in two different classes, that is control class and experiment class. Lessons learned in the control class using the usual method, or in other words not given treatment. In the meantime, the learning done in the experimental class used Syech Abdurauf As Singkili's learning based on Syron Abdurauf As Singkili, which has been adapted to the basic competence and competency standard. In addition to achievement tests, the effectiveness test for the model is also done by measuring the students' attitudes through questionnaires that have been disseminated by researchers and collaborating with teachers.

The terms used in calculating statistics are as follows:

a) Hypothesis

- Ho: There is an equal ability of the student achievement score between class X IPS 1 with class X IPS 3.

- H1: Absence of ability of student achievement score between class X IPS 1 with class X IPS 3.

b) Testing using two-sided test with significance level $\alpha=0.05$

c) Decision Test

- Ho accepted if significance $>0.05$

- Ho is rejected if significance $<0.05$

1) Cognitive Test

a. Normality Test Results

Conclusions from result of normality test of control group and experiment group using SPSS with amount of $n=28$ and $(\alpha)=0,05$, then obtained data as follows: SPSS statistical test result with technique Kolmogorov-Smirnov that pre-test of experiment class achievement have sig $0,226>0.05$ and while the result of post-test of experimental 
class achievement has sig value $0,107>0,05$, then data from experiment group can be interpreted normal distribution.

b. Homogeneity Test Results

From the calculation of homogeneity test of variances above, it can be seen sig value of pre-test data of 0.000 and post-test value of 0.913 . Because the significance value is less than 0.05 , it can be concluded that the pre-test and control and experimental grade data are controlled by homogeneity (see appendix).

c. T-Test Result

With SPSS 17 using Independent Tests to search for averages before and after treatment in the experimental class Experimental Class Here is the conclusion of the Test Result: Test Analysis with SPSS using Independent-Sample T-Test to find the mean before and after treatment in the control class. Based on the above statistical test results obtained the average test results for the control class that is before treatment 51.43 and after treatment 58.57 While Test $\mathrm{T}$ of 2.279 with a significance level of $0.000<0.025$ then Ho is rejected, so the average before and after the treatment of control classes are not the same.

2) Improvement Test (Experiment Class Pre Test and Post Test of Experiment Class.)

a. Normality Test Results

Conclusions from result of normality test of control group and experiment group using SPSS with amount of $n=28$ and $(\alpha)=0,05$, then obtained data as follows: SPSS statistical test result with technique Kolmogorov-Smirnov that pre-test of experiment class achievement have sig $0,200>0.05$ and while the result of post-test of experimental class achievement has sig value $0,77>0,05$, then data from experiment group can be interpreted normal distribution.

b. Homogeneity Test Results

From the calculation of the test of homogeneity of variances above, it can be seen the sig value of pre-test data and the post-test value of 0.430 . Because the value of significance is less than 0.900 , it can be concluded that the data of pre-test value and control and experiment class check-grade is homogeneity.

\section{c. T-Test Result}

With SPSS 17 using Paired Sample T-Test to search for averages before and after treatment in the control class and Experimental Class Here is the conclusion of the Test Result: Test Analysis with SPSS using Independent-Sample T-Test to find the mean before and after treatment in the control class. Based on the above statistical test results obtained the average test results for the control class that is before treatment 29.64 and 
after treatment 72.86 While the T-Test of 0.711 with a significance level of $0.000<0.025$ then $\mathrm{Ho}$ is rejected, so that the average before and after the control class treatment is not the same.

3) Effectiveness Test

a. Normality effectiveness test.

Conclusions from result of normality test of control group and experiment group using SPSS with amount of $n=28$ and $(\alpha)=0,05$, then obtained data as follows: SPSS statistical test result with technique Kolmogorov-Smirnov that pre-test of experiment class achievement have sig $0,625>0.05$ and while the result of post-test of experimental class achievement has sig value $0,085>0,05$, then data from experiment group can be interpreted normal distribution.

b. Homogeneity Test Results

From the calculation of the test of homogeneity of variances above, it can be seen the value of sig pre-test data of 0.140 and post-test value of 0.480 Because the significance value is smaller than 0,05 , it can be concluded that the data value of pre-test and post-test control and experiment class is homogeneity.

c. T-Test Result

With SPSS 17 using paired Sample T-Test to search for averages before and after treatment in the control class and Experimental Class Here is the conclusion of the Test Result: Test Analysis with SPSS using Paired-Sample T-Test to find the mean before and after treatment in the control class. Based on the above statistical test results obtained the average test results for the control class that is before treatment 66.42 and after treatment 73,92 While T-test of 0.037 with significance level $0.000<0.025$ then Ho is rejected, so the average before and after the treatment of control class is not the same.

\section{CONCLUSION}

Based on the results of research and discussion then taken the conclusion of research on the development of history-based learning model manuscript Syech Abdurrauf As Singkili for awareness of gender equality of students in Senior High School 1 Gunung Meriah. the researcher divides the conclusions into namely; (1) Preliminary research results; (2) Model development results; (3) Suggestions in detail as follows

a. Preliminary Research Results

Based on the observation, the teacher uses more lectures, so the learning is much centred on the teacher (teacher centred). In addition, in some meetings, the teacher also held a discussion or group work to the students. But this is still not effective because of not optimal yet role of students less conducive students in paying attention to the discussion. 
As for the understanding of gender equality awareness of students is still relatively low. Students tend to override the value of equivalence values in the class such as women should not be head of the class, group division still in the form of a group of men with men and women with women only. From the questionnaire results also shows that students understand in gender equality but the application is still far from expectations. Equal gender equality is beneficial not only in the school environment but in the community.

Students' knowledge of the ulema from Aceh Singkil Syech Abdurrauf As Singkili is quite good. Because some teachers have taught the value of the value of local nurseries to students. Moreover, Syech Abdurrauf As Singkili is the first scholar to make Arabic Quran Malay and as a preacher tariqat in the archipelago. Thus as a charismatic cleric of Aceh, of course, the writings of the book of Syech Abdurrauf As Singkili be useful science, especially the problem of gender equality.

b. Learning Model Development Outcomes.

The initial descriptions of the historical learning model developed by researchers and collaborated with teachers. It is hoped that through the history-based learning model the value of Syech Abdurrauf Manuscript value is expected to give students knowledge of gender equality awareness of both school and community environments.

Prior to the development of the model then the researcher performs the instrument validity test to the expert. Data analysis by the learning expert is aimed to determine the feasibility of the model to be applied in the learning process. Based on the assessment of the supporting theories, syntax, social system, reaction principle, support system, impact side effect, and implementation of learning with 31 indicators, the average result was 4.6. This shows the learning model developed has a Good category.

Data analysis by the expert of learning is aim to know RPP that is used feasibly will be used model that will be applied in the learning process. Based on the assessment of the above aspects with 14 indicators in the RPP format it can be concluded that generally the instrument can be used with the record should be revised about the method used should be adjusted again. The average result is 4.78.It shows the learning model developed has a very good category

Based on the results of the above assessment, the conclusion obtained is the material or teaching materials can be used by revising the parts that have been determined by the expert. In general, the assessment criteria can be seen in the percentage table and the result of validation test of teaching materials that will be used as a model in learning history. Based on the results of the assessment that has been done, in general, questions can be used without revising. The average result is 4.3. This shows the problem of learning that developed has a good category. 


\section{REFERENCES}

Abdullah, T. (1966). "Di Sekitar Pengajaran Sejarah yang Reflektif dan Inspiratif”.Sejarah. No. 6 Februari 1996. Jakarta: Gramedia

Abdullah, T., Suryomihardjo, A. (1985). Ilmu Sejarah dan Historiografi Arah dan Perspektif. Jakarta: Gramedia.

Abdurauf al-Fansuri al-Jawi, 1990). Tarjuman Al-Mustafid, cet. IV, Jakarta: Dar Al-Fikr.

Abdurrahman, M. 2012. Pendidikan Bagi Anak Berkualitas Belajar . Jakarta : Rineka Cipta dan Departemen Pendidikan dan Kebudayaan.

Adisusilo, S. 2012. Pembelajaran Nilai Karakter : Konstruktivisme dan VCT sebagai Inovasi Pendekatan Pembelajaran Afektif. Jakarta : PT Raja Grafindo Persada.

Agung, L. 2012. " Implementasi Model Pembelajaran IPS Terpadu : Suatu studi Evaluatif di SMP Kota Surakarta" Jurnal Pendidikan dan Kebudayaan, Vol 18, No.2, hlm 1-22. Surakarta : FKIP Universitas Sebelas Maret.

Ajidar Matsyah. 2013. Jaringan Ulama Ulama dalam Manuskrip. Seminar Serantau Kajian Manuskrip Melayu dan Kearifan Tempatan.

Alberta, Fokus on Inquiry: A Teacher's Guide to Implementing Inquiry-Based Learning. (Alberta Learning Canada 2004 ) Chapter 1.

Alexon dan Sukmadinata, N. S. 2010 "Pengembangan Model Pembelajaran TerpaduBerbasis Budaya Untuk Meningkatkan Apresiasi Siswa Terhadap Budaya Lokal". Cakrawala Pendidikan. Th. XXX no.2 hlm.189-203. Bengkulu : FKIP Universitas Bengkulu dan Pascasarjana Universitas Pendidikan Indonesia.

Amin, M., (1987), Mengajar Ilmu pengetahuan alam (IPA) dengan menggunakan metode discovery dan inkuiri, Yogyakarta. Departemen Pendidikan Dan Kebudayaan Direktorat Jendral Pendidikan dan Tinggi.

Anderson, L. W. \& Krathwohl, D. R. 2010. Kerangka Landasan Untuk Pembelajaran, Pengajaran, dan Asesmen. Yogyakarta : Pustaka Pelajar

Ankersmit, F. R. 1987. Refleksi tentang Sejarah: Pendapat-Pendapat Modern tentang Filsafat Sejarah. Jakarta: Gramedia..

Arabi, Muhyiddin Ibn 1980, Fushûsh al-Hikam, Beirut: Dâr al-Kitab al-Arabi.

Arends, R. 2008. Learning To Teach. Terjemahan oleh H. P. Soetjipto dan M. S. Soetjipto. Edisi Ketujuh. Yogyakarta : Pustaka Pelajar.

Arifin, Z. 2014. Evaluasi Pembelajaran Prinsip Teknik Produser. Bandung : PT Remaja Rosdakarya.

Arikunto, S., Suhardjono, dan Supardi. 2012. Penelitian Tindakan Kelas. Jakarta : PT Bumi Aksara.

Depdikbud.

Dimyati dan Mudjiono. 2013. Belajar dan Pembelajaran. Jakarta : Rineka Cipta.

Djaali. 2013. Psikologi Pendidikan. Jakarta : PT Bumi Aksara. 
Djamarah, S. B. 2012. Prestasi Belajar dan Kompetensi Guru. Surabaya : Usaha Nasional.

Donald Ary, Dkk. Introduction to research in education, Terj. Arif Furqon (Surabaya: UsahaNasional, 1982)

Echols, John M. dan Hassan Shadily, 1983, Kamus Inggeris Indonesia, Cet. I; Jakarta: Gramedia, cet. X.

Elmubarok, Z. 2009. Membumikan Pendidikan Nilai. Bandung : Alfabeta.

Emi Suhaimi, Wanita Aceh dalam Pemerintahan dan Peperangan ,Banda Aceh:Gua Hira, 1993

Eriyanto. 2004. Analisis Wacana, Pengantar Analisis Isi Media. Yogyakarta : LKIS

Fakih, Mansur 1996, Analisis Gender dan Transformasi Sosial.Cet. I;Yogyakarta: Pustaka Pelajar.

Fang. Y Liaw.2010. Sejarah Kesustraan Melayu Klasik. Jakarta : Obor

Fathurrahman, Oman. Tarekat Syattariyah di Minangkabau. Prenada media Jakarta. 2008

Fatturhaman. Oman. 2001. Naskah dan Rekonstuksi Islam Lokal : Ithaf al Dhaki bi Sharh al Tuhfah al - Mursalah Ilah Ruh al - Nabi (Karya Ibrahim al - Kurani), dalam : M Yusuf dkk, penelitian Naskah Nusantara dari Sudut Padang Kebudayaan Nusantara. Padang : Fakultas Sastra UNAND.

Fatturhaman. Oman.1999 .Tanbi Al- Masyi, Meyoal Wujud : Kasus Abdurrauf Singkel di Aceh Abad 17. Bandung : EFEO \& Mizan.

Gall. M. D.Gall, J. P. \& Borg, W. R. 2003. Educational Research: An Introduction. New York: Longman.

Gottschalk, l. (1973). Mengerti Sejarah. Jakarta: UI Press.

Hadi, Abdul WM. Tasawufyang tertindas, paramadina jakarta.2001

Hall, B. 1973. Value Clarification as Learning Process. New York: Paulist Press.

Hamalik, 0. 2012. Proses Belajar Mengajar. Jakarta : PT Bumi Aksara.

Hamka. Tasawuf Modern . Jakarta. Pustaka Panjimas. 1983

Hamruni. 2012. Strategi Pembelajaran. Yogyakarta : Insan Madani.

Hasan, H. S. (1995). Pendidikan Ilmu Sosial. Jakarta: Proyek Pendidikan Tenaga

Hasan, H. S. (1999). "Pendidikan Sejarah untuk Membangun Manusia Baru Indonesia". Mimbar Pendidikan. Nomor 2, Tahun XVIII, 1999. Bandung: University Press IKIP Bandung.

Hasan, H.S. (2003). "Strategi Pembelajaran Sejarah pada Era Otonomi Daerah sebagai Implementasi Kurikulum Berbasis Kompetensi" dalam Sjamsuddin, H.\& Suwirta, A. Historia Magistra Vitae: Menyambut 70 Tahun Prof. Dr. Hj.Rochiati Wiriaatmadja, M.A. Bandung: Historia Utama Press.

Hasjmi, A. 1980. Syech Abdurrauf Syiah Kuala, Ulama Negarawan yang Bijaksana, dalam Universitas Syiah Kuala Menjelang 20 Tahun. Medan

Hasjmy. A. 1977. 59 Tahun Aceh Merdeka di Bawah Pemerintahan Ratu, Jakarta: Bulan Bintang. 
Hill, C. P. (1956). Saran-Saran tentang Mengajar Sejarah.Terj. Hasan Wirastina. Jakarta: Kepustakaan Perguruan Kementrian PP dan K.

Hogan, C. F. 2007. Facilitating Multicultural Groups : A Practical Guide. Philadelphia, PA : Kogan Page.

Hosnan, M. 2014. Pendekatan Saintifik dan Kontekstual Dalam Pembelajaran Abad 21. Bogor : Ghalia Indonesia.

Howe, L. W \& Howe, M. M. 1975. Personalizing Education: Values Clarification and Beyond. New York City. Hart Publishing Company, Inc.

Huda, M. 2013. Model-model Pengajaran dan Pembelajaran : Isu-isu Metodis dan Paradigmatis. Yogyakarta : Pustaka Pelajar.

Ibrahim, M., Rachmadiarti, F., Nur, M., dan Ismono 2000. Pembelajaran Kooperatif. Surabaya : Unesa University Press.

Illich, Ivan. 2001, Matinya Gender.Cet. III, Yogyakarta: Pustaka Belajar.

Isjoni. 2012. Cooperative Learning : Efektivitas Pembelajaran Kelompok. Bandung : CV Alfabeta.

Joyce, Weil \& Calhoun. Models of Teaching Model-model Pengajaran. Edisi Kedelapan. Yogyakarta : Pustaka Pelajar.

Karli, H. dan Yuliariatiningsih, M.S. (2003). Model-Model Pembelajaran. Bandung : Bina Media Informasi.

Kartodirdjo, S. (1992). Pendekatan Ilmu Sosial dalam Metodologi Sejarah. Jakarta: Gramedia

Kemendiknas Balitbang Puskur. 2010. Bahan Pelatihan Penguatan Metodologi Pembelajaran Berdasarkan Nilai-nilai Budaya Untuk Membentuk Daya Saing dan Karakter BAngsa Pengembangan Pendidikan Kewirausahaan. Jakarta : Kemendiknas Balitbang Puskur.

Kertih, I. W. 2003. "Pengembangan Model Pembelajaran IPS Berwawasan Sosial Budaya Untuk Meningkatkan Literasi Sosial Budaya pada Siswa Sekolah DAsar di KAbupaten Buleleng", Jurnal Pendidikan dan Pengajaran, th. XXXVI, no.2 hlm. 1-13. Singaraja : IKIP Negri Singaraja..

Ketelhut. D.J. 2004. Inquiry Learning in Multi-User Virtual Environment (Harvard Graduation School of Education ).

Kobayashi, H. (2010). Self-awareness and mental perception. Journal Indian Philosophy.

Lickona, T. 2012. Mendidik Untuk Membentuk Karakter : Bagaimana Sekolah dapat Memberikan Pendidikan tentang Sikap Hormat dan Bertanggungjawab. Jakarta : Bumi Aksara.

Lie, A. 2005. Cooperative Learning: Mempraktikan Cooperative Learning di Ruang-ruang Kelas. Jakarta: Grasindo

Lindsey, Linda L. 1990, Gender Roles a Sociological Perspective, New Jersey: Prentice Hall.

Lips, Hilary M. 1993, Sex \& Gender an Introduction, California, London, Toronto: Mayfield Publishing Company.

Molenda, M. In search of the ellusive ADDIE model. Performance improvement, 42 (5), 34-36. Submitted for publication in A. Kovalchick \& K. Dawson, Ed's, Educational Technology: An Encyclopedia. Copyright by ABC- Clio, Santa Barbara, CA, 2003. (http://www.indian.edu) 
Muchtar, S. Al. 2007. Epistemologi Pendidikan Ilmu Pengetahuan Sosial. Bandung : Gelar Pustaka Mandiri.

Muin, H. Abd. 1992, Fiqih Siyasah; Konsepsi Kekuasaan Politik dalam Al'Qur'an Cet. I; Jakarta: PT. Raja Grafindo Persada.

Mulyasa. E. 2005. Menjadi Guru Profesional. Cet 3. Bandung. PT Remaja Rosdakarya.

Mulyoto. 2014. Materi Kuliah Desain dan Model Pembelajaran. Surakarta: Magister Pendidikan Sejarah FKIP UNS.

Musyrifah Sunanto,2007. Sejarah Peradaban Islam Indonesia, Jakarta : Rajagrafindo Persada.

Rochat, P. (2003). Five levels of self-awareness at the unfold early in life. Consciousness and Cognition

seminar Kesadaran Sejarah di UNS, Surakarta, 5 Mei 1991.

Steffe Leslie P. \& Gale J. (Eds.) (1995). Constructivism in education. Hillsdale, NJ: Lawrence Erlbaum.

Sudjana, N. 2013. Dasar-dasar Proses Belajar Mengajar. Bandung : Sinar Baru Algesindo.

Sudjana, N. 2014 Penilaian Hasil Proses Belajar Mengajar. PT Remaja Rosdakarya.

Sugiyono. 2013. Metode Penelitian Pendidikan : Pendekatan Kuantitatif, Kualitatif dan R\&D. Bandung. CV Alfabeta.

Sukmadinata, N. S. 2013. Landasan Psikologi Proses Pendidikan. Bandung : PT Remaja Rosdakarya.

Sukmadinata, N. S. 2013. Metode Penelitian Pendidikan. Bandung : PT Remaja Rosdakarya.

Sulaiman. Isa M. Sejarah Aceh, Sebuah Gugatan Terhadap Tradisi. Pustaka Sinar Harapan. Jakarta. 1997.

Sulasmono, B. S. 2003. "Mengembangkan Kecerdasan Antar Pribadi Melalui Belajar Kooperatif”. Academika Edisi No.2 Tahun I 200. Salatiga: Dewan Pendidikan kota Salatiga.

Suparno, P. (2001). Filsafat Konstruktivisme dalam Pendidikan. Yogyakarta : Kanisius.

Suprijono, A. 2012. Cooperative Learning : Teori dan Aplikasi PAIKEM. Yogyakarta : Pustaka Pelajar. .

Suryo, D. "Kesadaran Sejarah Sebuah Tinjauan", makalah disampaikan dalam

Susanto, A. 2014. Teori Belajar dan Pembelajaran di Sekolah Dasar. Jakarta : Kencana Prenadamedia Group.

Susilo. 2004. Inquiry in English For Young Learners Class: Enhancing Children's Creativity and Critical Thinking. ( jurnal pendidikan dam pembelajaran ).

Toplak, M., \& Tannock, R. Time perception; modality and duration effect in ADHD. Journal of abnormal child psychology.

Von Glasserfield, E. (1995). A constructivist approach to teaching. In L. Steffe \& J. Gale (Eds.), Constructivism in education (pp. 3-16). Hillsdale, NJ: Lawrence Erlbaum. 
Winataputra, U. S., Pannen, P., Andriyani, D., Mustafa, D., Delfi, R., dan Suciati. 2007. Teori Belajar dan Pembelajaran. Jakarta : Universitas Terbuka.

Wiriatmadja, R. (1998). “Landasan Filosofis Kurikulum Pembelajaran Sejarah

Wiriatmadja, R. 2014. Metode Penelitian Tindakan Kelas. Bandung : PT Remaja Rosdakarya.

Yaumi, M. 2014. Prinsip-prinsip Desain Pembelajaran : Disesuaikan dengan kurikulum 2013. Jakarta : Kencana Prenada Media Grup. 